\title{
Variation of carbon uptake from forest species in Mexico: a review
}

\section{Variación de captura de carbono de especies forestales en México: una revisión}

\author{
Marín Pompa-García** and José Ángel Sigala-Rodríguez²
}

1 Universidad Juárez del Estado de Durango. Facultad
de Ciencias Forestales. Durango, Durango, México.

\author{
2 Instituto Nacional de Investigaciones Forestales, * Corresponding author. mpgarcia@ujed.mx \\ Agrícolas y Pecuarias. Campo Experimental Valle \\ del Guadiana. Durango, Durango, México.
}

\begin{abstract}
Currently, assessing carbon content in forest species is considered essential for programs designed to mitigate global warming. Although in Mexico these studies are becoming more numerous, we still do not know the state of the art in this scientific field. To our knowledge there is a lack of a systematic synthesis of the current condition of carbon sequestration from forest species in Mexico. This would be a useful baseline for scientists interested in further developing carbon studies. The aim of the present study is to analyze the variations of carbon uptake in Mexican forest species. From a comprehensive literature review of indexed journals and specialized databases, this study records the efforts made to record carbon storage rates in Mexican forests based on species, tree components, regions and ecosystems. The results identify those areas that are frequently the subject of research, as well as where opportunities exist and where efforts should be targeted, particularly in rainforests that have been the subject of very few research studies. This study to generate the first Mexican data base that summarizes state of the art data on the topic under study and contributes to a better understanding of potential functional relationships between diversity and carbon sequestration in forest ecosystems in Mexico.
\end{abstract}

KEYWORDS: carbon-content, carbon-storage, $\mathrm{CO}_{2}$, database, Mexican forest, trees.

\section{RESUMEN}

Actualmente, evaluar contenido de carbono en especies forestales es considerado esencial en programas diseñados para mitigar el calentamiento global. Aunque en México estos estudios son cada vez más numerosos, aún no se conoce el estado del arte en este campo científico. A consideración de los autores, se carece de una síntesis que sistematice las condiciones actuales de captura de carbono a partir de especies forestales en México. Esto podría ser una línea base útil para científicos interesados en desarrollar más estudios de carbono. El objetivo del presente estudio fue analizar las variaciones de captura de carbono en especies forestales mexicanas. A partir de una exhaustiva revisión de literatura de revistas indexadas y bases de datos especializados, este estudio registra los esfuerzos hechos para documentar las tasas de almacenamiento de carbono en los bosques mexicanos, según las especies, compartimentos del árbol, regiones y ecosistemas. Los resultados identifican aquellas áreas que frecuentemente son sujetas de investigación, así como aquellas donde existen áreas de oportunidad y hacia donde se deben dirigir los esfuerzos de investigación, particularmente en las selvas donde se han realizado pocos estudios. Este estudio genera la primera base de datos mexicana que resume el estado del arte en el tópico bajo estudio y contribuye a un mejor entendimiento de las potenciales relaciones funcionales entre diversidad y captura de carbono en los ecosistemas forestales en México.

Palabras Clave: contenido de carbono, almacenamiento de carbono, $\mathrm{CO}_{2}$, base de datos, bosques mexicanos, árboles. 


\section{INTRODUCTION}

People worldwide recognize that forest ecosystems serves as a major carbon sink and as the major biological scrubber of atmospheric greenhouse gases and particularly; thus, this ecosystem is capable of sequestering large amounts of atmospheric carbon dioxide (Cunha-e-Sá, Rosa and Costa-Duarte, 2013; Dhillon and von Wuehlisch, 2013). Global $\mathrm{CO}_{2}$ emissions continue to increase (International Energy Agency [IEA], 2011). According to the International Energy Agency (IEA, 2015), global carbon-dioxide $\left(\mathrm{CO}_{2}\right)$ emissions reached a record high of 32.2 gigatonnes (Gt) in 2013 (e.g. 2.17\% more than in 2012).

In this regard, many efforts are being made to improve the estimation of forest carbon $(\mathrm{C})$ stocks worldwide as a prerequisite to accurately assessing the contribution of forest ecosystems to the net global carbon budget (Zhang, Wang, Wang and Quan, 2009; Babst et al., 2014; Poulter et al., 2014). Prominent studies have demonstrated that assuming generic simplification (such as tree biomass consisting of $50 \%$ carbon) may produce misleading estimates (Ravindranath and Ostwald, 2008; Martin and Thomas, 2011; Castaño-Santamaría and Bravo, 2012). As a result, Thomas and Martin (2012) conducted a comprehensive synthesis of existing literature and presented a global synthesis of carbon content in tissues of live trees. Their findings have reduced the uncertainty of carbon calculation and may reduce biases such estimates of forest carbon stock and fluxes in forest systems.

The Mexican forests have been documented as diverse in terms of species (Sarukhán et al., 2009) and have great potential as a carbon sink (Torres-Rojo and Guevara-Sanginés, 2002; Comisión Nacional Forestal , 2012), and therefore they represent an opportunity to contribute to refining assessments of carbon variability across Mexico's ecosystems. Many studies for Mexico use a constant value for carbon concentration (often 50\%) to model carbon flux in different ecosystems, providing a limited understanding of the role of forests as carbon sink zones (Lamlom and Savidge, 2003).

Consequently, it is important to review and highlight the contribution of Mexican literature on this issue. The systematization of this collection in a database would provide an overview to identify the background, knowledge gaps and trends that research has taken, depending on the tree species, geographical region and ecosystem, among other data.

\section{OBJECTIVES}

In this study, we aimed to comprehensively review the existing literature related to forest tree species in Mexico to (1) evaluate variation in wood carbon concentration across taxonomic groups and climatic regions in Mexico; (2) document the general scope of carbon storage of aboveground biomass for each type land use, and (3) make this comprehensive review easily available using internet technology.

\section{MATERIALS AND METHODS}

A systematic review of the literature was conducted using major databases such as the Web of Science, Science Direct, Google Scholar, Sistema Regional de Información en Línea para Revistas Científicas de América Latina, el Caribe, España y Portugal and Scientific Electronic Library Online. Different combinations from a predefined list of keywords were used, such as "carbon," "tree," "carbon content," "concentration," "aboveground carbon," "terrestrial ecosystems," "forest species" and "Mexico." Papers in indexed and peer-reviewed journals that were published until December 2016 were included. All gray literature (theses, technical reports, conference abstracts, seminars and scientific meetings) was excluded from the search.

In order to ensure the reliability and comparability of the review data, it was confirmed that the papers included the following criteria: 1) the description of the site and ecosystem where the study was conducted;2) the land use type was specified; 3) where appropriate, the botanical name of families or studied species were provided; 4) tree or shrub species were included, and 5) estimates of carbon storage in the study site were explicitly described in megagrams per hectare in a given case, to document the concentration of carbon (\%) in the biomass of the species 
TABLE. 1. Scientific journals that published articles related to the evaluation of storage capacity and carbon concentration in tree species of forest ecosystems.

\begin{tabular}{|c|c|c|c|c|c|c|}
\hline Journal & Country & $1996-2000$ & $2001-2005$ & $2006-2010$ & $2011-2016$ & Total \\
\hline Agrociencia & Mexico & & 1 & 2 & 2 & 5 \\
\hline Agroforestry Systems & International Soc. & & & 1 & 1 & 2 \\
\hline Arid Land Research and Management & International Soc. & & & 1 & & 1 \\
\hline Avances en Investigación Agropecuaria & Mexico & & & & 1 & 1 \\
\hline Bosque & Chile & & & & 2 & 2 \\
\hline Carbon Balance and Management & International Soc. & & & 1 & & 1 \\
\hline Ciencia UANL & Mexico & & 1 & 1 & 1 & 3 \\
\hline Colombia Forestal & Colombia & & & & 1 & 1 \\
\hline Ecology & United States & 1 & 1 & & & 2 \\
\hline Ecosistemas y Recursos Agropecuarios & Mexico & & & & 1 & 1 \\
\hline Forest Ecology and Management & United States & & & 2 & & 2 \\
\hline Forest Systems & Spain & & & & 1 & 1 \\
\hline Foresta Veracruzana & Mexico & & 2 & 2 & & 4 \\
\hline Forestry & United States & & & 1 & & 1 \\
\hline Interciencia & Venezuela & & & 1 & 1 & 2 \\
\hline Madera y Bosques & Mexico & & 2 & 2 & 3 & 7 \\
\hline $\begin{array}{l}\text { Phyton-International Journal of Experimen- } \\
\text { tal Botany }\end{array}$ & Argentina & & & & 1 & 1 \\
\hline PlosONE & International Soc. & & & & 1 & 1 \\
\hline Ra Ximhai & Mexico & & & 1 & & 1 \\
\hline $\begin{array}{l}\text { Revista Chapingo Serie Ciencias Forestales } \\
\text { y del Ambiente }\end{array}$ & Mexico & & 1 & 1 & 5 & 7 \\
\hline Revista Fitotecnia Mexicana & Mexico & & & 3 & & 3 \\
\hline Revista Latinoamericana de Recursos & Mexico & & & 2 & 2 & 4 \\
\hline Naturales & & & & & & \\
\hline Revista Mexicana de Ciencias Agrícolas & Mexico & & & & 3 & 3 \\
\hline Revista Mexicana de Ciencias Forestales & Mexico & & & & 10 & 10 \\
\hline Terra Latinoamericana & Mexico & & 1 & 1 & & 2 \\
\hline Tropical and Conservation Science & International Soc. & & & & 1 & 1 \\
\hline Tropical and Subtropical Agroecosystems & Mexico & & & & 1 & 1 \\
\hline Wetlands Ecology and Management & International Soc. & & & & 1 & 1 \\
\hline Total & & 1 & 9 & 22 & 39 & 71 \\
\hline
\end{tabular}


studied. We use the term "concentration" explicitly when referring to elemental concentrations in wood or leaf tissue (Whitehead, 2000).

A database was created with 71 records of studies related to the evaluation of carbon storage and concentration in tree species of different ecosystems in Mexico. Papers published in 28 journals were found that were produced by 14 national publishers and where $73.2 \%$ of the studies were published. Published papers correspond to the last 20 years. Most papers (39) have recently been published during the last five years (Table 1).

Data from each document was recorded in a database using Microsoft Access 2010 and Microsoft Excel, and was compiled so it could be accessed on a website. The complete database is available as supplementary material (Tabular_data_provided_as_supplementary_material. xls). Each record was classified by species, genus, family, ecosystem, land use system and Mexican state where the study had been conducted; also, a full reference citation including the journal information was recorded for each study.

For statistical analysis, each record was reclassified by assigning the field for taxonomic group with one of two values (conifer, broadleaf species) and another field related to the climatic region with one of two values (temperate, tropical/subtropical). Moreover, each record was assigned the value of the concentration of carbon per species mentioned by the author.

\section{RESULTS}

\section{Ecosystems studied}

From the papers found, $25(30 \%)$ are related to studies in coniferous tree ecosystems, the most frequently studied ecosystem. The second most frequently studied ecosystem is pine-oak forest with 18 papers. The least explored ecosystems were Quercus forests and evergreen rain forest (Fig. 1). Families most frequently mentioned in the studies are Pinaceae, Fagaceae and Fabaceae. Moreover, Pinus (Pinaceae), Acacia (Fabaceae) and Quercus (Fagaceae) were the most frequently genera mentioned in the studies.

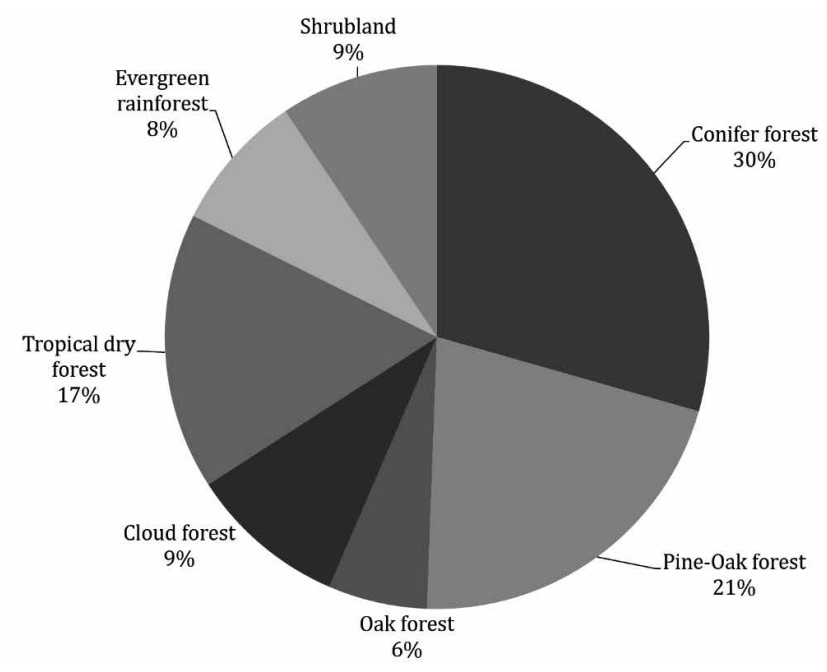

Figure 1. Main ecosystems documented by number of studies conducted.

Geographically, the largest number of studies has been conducted in the states of Veracruz (11) and Nuevo Leon (10) (Fig. 2). In Veracruz, the 11 studies are mainly conducted on plant communities of dry forests and cloud forest; meanwhile, in Nuevo Leon 10 studies have been particularly conducted on the Tamaulipan thornscrub, as well as on pine-oak forests.

\section{Concentration of carbon in aerial biomass}

From the papers analyzed here, 60 contain information related to the concentration of carbon (\%) in biomass at the species level or for other taxonomic groups. A fraction of predefined carbon value or taken from another bibliographic reference was used in 34 documents. In contrast, only 26 papers specify the concentration of carbon in the biomass of the species, estimated by chemical analysis in the laboratory. Broadleaved species were most frequently analyzed and are mainly represented in tropical/subtropical climates, while coniferous species were represented in temperate climates (Table 2).

In those laboratory studies that determined the concentration of carbon, we found an overall average of $47.7 \%$, which coincides with the value predetermined by the Intergovernmental Panel on Climate Change (IPCC, 


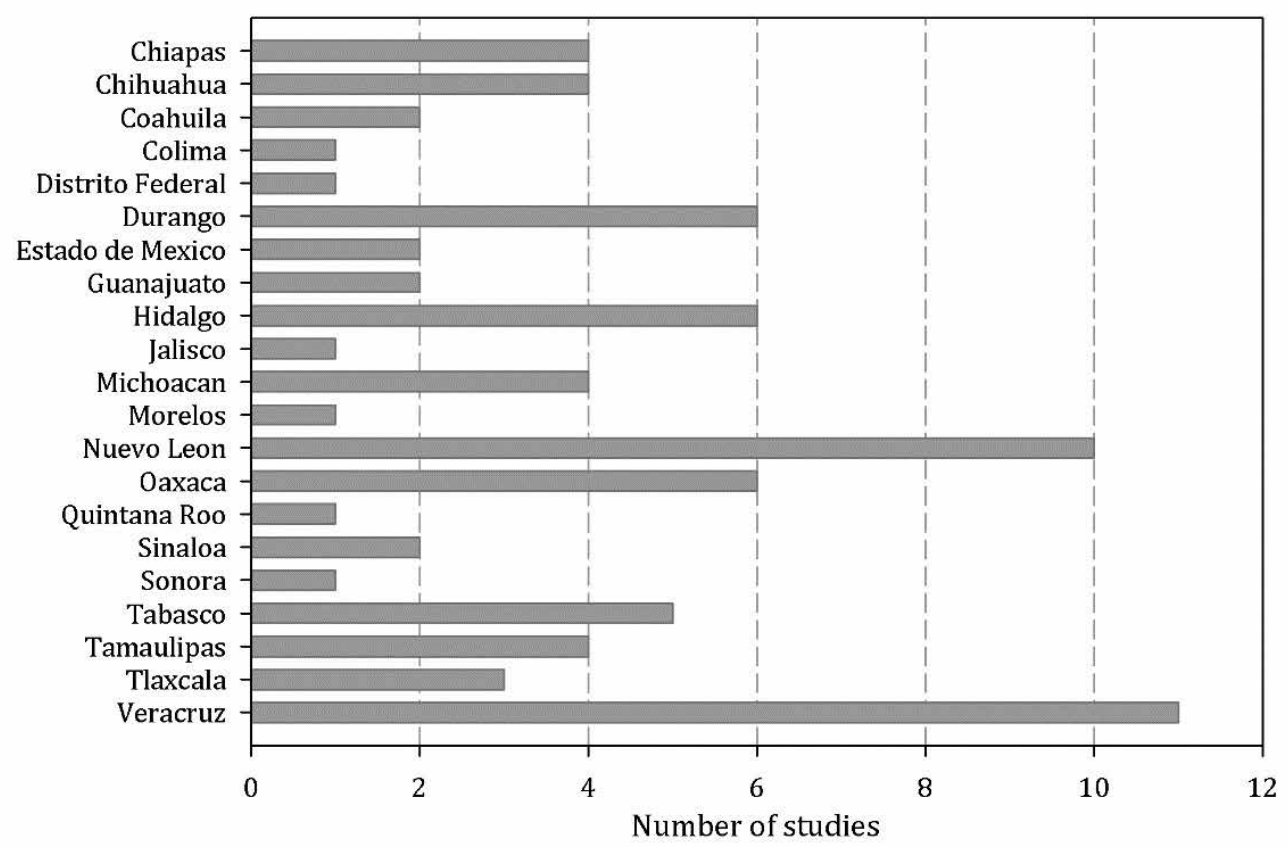

Figure 2. Number of studies conducted per state related to carbon concentration and storage for tree species in Mexico.

TABle 2. Concentration of carbon (\%) in biomass of tree species grouped by taxa and climatic region. Mean \pm confidence interval (95\%).

\begin{tabular}{|c|c|c|c|c|c|c|}
\hline \multirow{2}{*}{ Climate } & \multirow{2}{*}{ Group } & \multicolumn{2}{|c|}{ Estimated in laboratory } & \multicolumn{2}{|c|}{ Based on references } & \multirow{2}{*}{ IPCC (2006)" } \\
\hline & & Species (Ref) & $C(\%)$ & Species (Ref) & $C(\%)$ & \\
\hline \multirow[t]{2}{*}{ Temperate } & Conifers & $26(14)$ & $49.3 \pm 0.88$ & $18(14)$ & $49.2 \pm 0.67$ & $47-55$ \\
\hline & $\begin{array}{c}\text { Broadleaf } \\
\text { species }\end{array}$ & $28(6)$ & $45.5 \pm 1.16$ & $9(7)$ & $48.1 \pm 1.47$ & $46-50$ \\
\hline \multirow[t]{3}{*}{ Tropical/subtropical } & Conifers & NA & NA & $5(3)$ & $50.4 \pm 1.17$ & $44-49$ \\
\hline & $\begin{array}{c}\text { Broadleaf } \\
\text { species }\end{array}$ & $60(11)$ & $47.6 \pm 0.47$ & $112(21)$ & $48.3 \pm 0.49$ & $44-49$ \\
\hline & General & $114(26)$ & $47.7 \pm 0.46$ & 144 (34) & $48.5 \pm 0.39$ & 47 \\
\hline
\end{tabular}

*Fraction of carbon in aboveground forest biomass defined by the Intergovernmental Panel on Climate Change (Intergovermental Panel on Climate Change [IPCC], 2006). Ref = number of references, $C(\%)=$ concentration of carbon in aerial biomass, NA = Not available.

2006) for estimating carbon in aerial forest biomass (Table 2). In general, no differences in the concentration of carbon between species of temperate and tropical/subtropical climates $(F=0.03, p=0.867)$ are shown; however, significant differences were found between taxonomic groups $(F=39.88, p<0.0001)$, with the highest concentration of carbon in conifers $(49.3 \%)$ when compared with broadleaved species (46.5\%) (Fig. 3).
A temperate forest has high concentrations of carbon in biomass, particularly in Pinus species. Silva-Arredondo and Návar-Cháidez (2009) found the highest values for Pinus engelmannii, Pinus cooperi and Pinus teocote. The genus Juniperus also has high concentrations of carbon, with values ranging from 49 to $51.2 \%$, reported by Yerena-Yamallel et al. (2012), Jiménez-Pérez, TreviñoGarza and Yerena-Yamallel (2013), Razo-Zárate et al. 


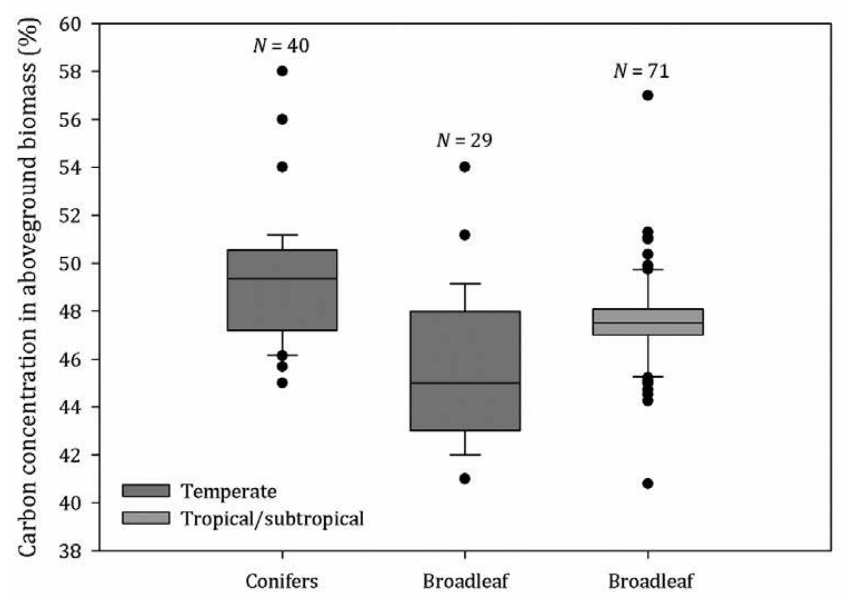

Figure. 3. Comparison of the concentration of carbon in forest biomass of selected species determined by laboratory analysis of samples.

$N=$ number of values reported at the species level (in some cases a single species was included more than once).

(2015). Moreover, from the same group of conifers, RazoZárate, Gordillo-Martínez, Rodríguez-Laguna, Maycotte-Morales and Acevedo-Sandoval (2013) and Razo-Zárate, Gordillo-Martínez, Rodríguez-Laguna, Maycotte-Morales and Acevedo-Sandoval (2015) reported that Abies religiosa had lower concentration of carbon $(45 \%)$.

From the group of broadleaved species from temperate regions, the genus Quercus had an average carbon value of $48.5 \%$ (Silva-Arredondo and Návar-Cháidez, 2009, Aguirre-Calderón and Jiménez-Pérez, 2011, Jiménez-Pérez et al., 2013) while species of this group with lower concentrations of carbon correspond to different shrubby species as stated by Razo-Zárate et al. (2015) in Abies forest.

In regions with tropical/subtropical climates, we found studies with carbon analysis in laboratory were limited to only broadleaved species, which had concentrations between $40.8 \%$ and $57 \%$. The highest concentration was recorded for Gliricidia sepium (Villanueva-López, Martínez-Zurimendi, Casanova-Lugo, Ramírez-Avilés and Montañez-Escalante, 2015) and the lowest concen- tration was documented for Inga jinicuil in temperate deciduous forest (Hernández-Vásquez et al., 2012).

The Fabaceae family was the most well-represented in this group of species, which is reported to have an average of $47.7 \%$ of carbon in biomass; the genera with relatively high carbon values were Gliricidia, Caesalpinia and Swartzia (Bautista-Hernández and Torres-Pérez, 2003; Jaramillo et al., 2003; Villanueva-López et al., 2015). In addition, the genus Acacia (Fabaceae) had a higher frequency, although lower concentration of carbon $(45.9 \%)$ (YerenaYamallel et al., 2012) (see supplementary material).

\section{Carbon storages in forest ecosystems}

Figure 4 shows a comparison of carbon storages or reservoirs in forest ecosystems classified by plant community. The vegetation types with higher carbon stocks are coniferous forests (106 $\mathrm{Mg} \mathrm{ha}^{-1}$ ) and evergreen rainforest (106.9 $\left.\mathrm{Mg} \mathrm{ha}^{-1}\right)$, although the latter have a greater variation because of different land uses, reported as being up to $353 \mathrm{Mg} \mathrm{ha}^{-1}$ in primary natural forests (Bautista-Hernández and Torres-Pérez, 2003). Scrubland has the lowest average carbon reserves $\left(12.5 \mathrm{Mg} \mathrm{ha}^{-1}\right)$ with maximum values of up to $28.7 \mathrm{Mg} \mathrm{ha}^{-1}$ in subtropical scrubland (Ordóñez et al., 2008).

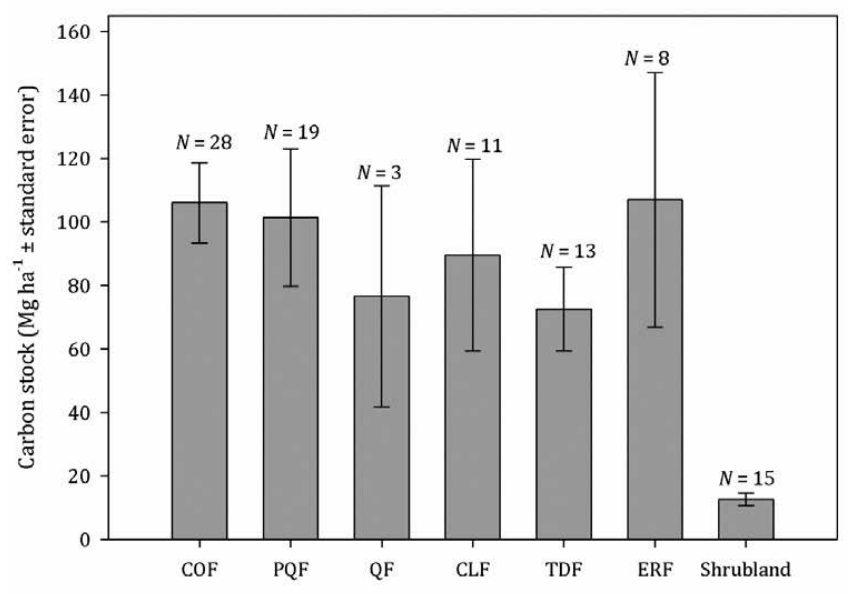

FIGURE. 4. Storage rates of aboveground carbon per vegetation type. $\mathrm{QF}=$ Oak Forest, $\mathrm{COF}=$ Coniferous Forest, $\mathrm{PQF}=$ Pine-Oak Forest, $\mathrm{CLF}=\mathrm{Cloud}$ forest, $E R F=$ Evergreen rainforest, $T D F=$ Tropical Dry Forest. $N=$ number of references used to obtain the average. 
However, wide variation has also been observed in carbon storage rates according to the land use type in forest ecosystems. It is noted that Natural Protected Areas have the highest carbon stocks in aerial biomass with average values of $135.3 \mathrm{Mg} \mathrm{ha}^{-1}$, and with values recorded by Pineda-López et al. (2013) of up to $171.9 \mathrm{Mg} \mathrm{ha}^{-1}$ in Abies Forests. Primary forests and forests under management are also shown to have significant reserves of aboveground carbon, whose documented stocks averaged $105.1 \mathrm{Mg}$ $\mathrm{ha}^{-1}$ and 115.4 $\mathrm{Mg} \mathrm{ha}^{-1}$, respectively. Other land uses with lower carbon storage rates are secondary forests $(51.2 \mathrm{Mg}$ $\left.\mathrm{ha}^{-1}\right)$, reforestation areas and commercial plantations (45.6 $\mathrm{Mg} \mathrm{ha}^{-1}-62.8 \mathrm{Mg} \mathrm{ha}^{-1}$ ) and agroforestry systems (35.8 $\mathrm{Mg} \mathrm{ha}^{-1}$ ) (Fig. 5).

\section{DISCUSSION}

In general, carbon storage rates have been documented most frequently for both coniferous and pine-oak forests; however, commercially valuable species have attracted the most interest and are well documented. Moreover, few studies have estimates carbon stocks in rainforests, particularly in evergreen rain forests, although the largest source of emissions of greenhouse gases in these regions is

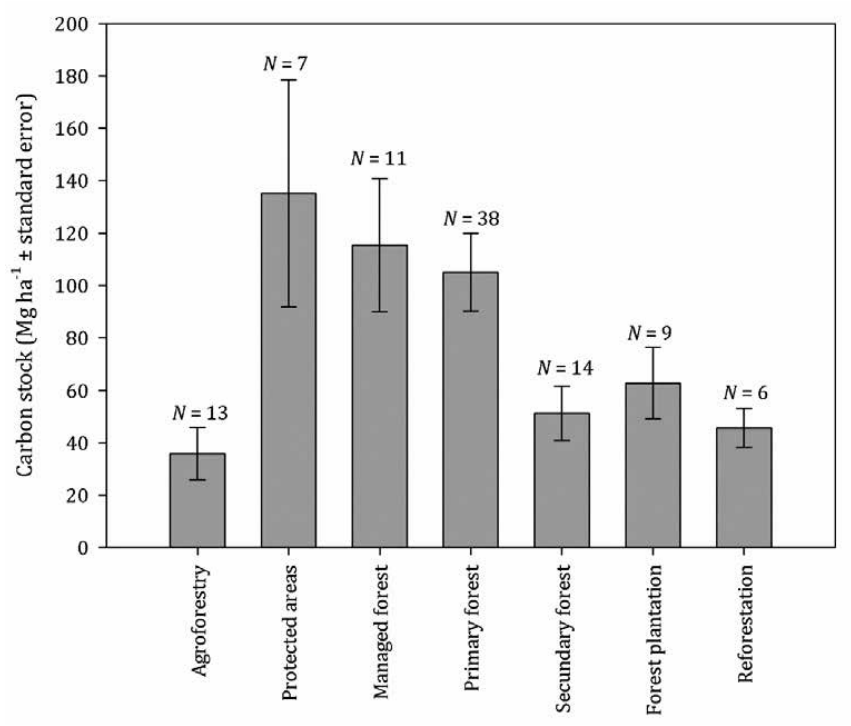

FIGURE. 5. Storages of aboveground carbon based on land use type in forest ecosystems.

$N=$ number of references used to obtain the average. derived from the degradation and deforestation in these ecosystems (Gibbs et al., 2007).

This review shows that differences exist in the concentration of carbon between conifers and broadleaf species, coinciding with the findings of Lamlom and Savidge (2003) for North American species, and with recent revisions made by Weedon et al. (2009) and Thomas and Martin (2012) in species from different climatic regions worldwide. These differences can be attributed to some extent to a higher concentration of nonstructural carbohydrates in wood of conifers (Hoch et al., 2003; Johnson et al, 2012.), or to the difference in the composition of lignin between angiosperms and gymnosperms (Campbell and Sederoff, 1996).

In contrast, no differences in the concentration of carbon were observed between forests of different climatic regions. However, a higher concentration of carbon in tropical/subtropical climates was reported for broadleaved species. For example, Villanueva-López et al. (2015) quantified a proportion of $57 \%$ of carbon contained in the total biomass of Gliricidia sepium. Nevertheless, this carbon concentration is much higher than the value reported $(44 \%)$ by Alvarado, Rodríguez and Cerrato (2007) for the same species in Costa Rica. In this sense, Ordóñez et al. (2015) mentioned that the properties of wood are variable and that attributes can change according to the local conditions such as geographical area and climate, even in tropical species. Elias and Potvin (2003) remark that trunk carbon concentration across species varies with environmental and/or growth factors.

Regarding carbon stocks for different ecosystems, coniferous and dry forests have the highest values per unit area; although tropical forests have greater variation that is attributable to the limited number of studies in these areas. In contrast, shrubland had lowest carbon stocks. This coincides with a recent analysis on carbon storage and fluxes in Mexico, where the results show that rainforests had higher stocks and productivity values, while shrubland had lower values (Murray-Tortarolo et al., 2016). Furthermore, Baral, Malla and Ranabhat (2009) report that there is considerable variation in aboveground carbon storage rates depending on the type of vegetation 
and its geographical location; however, accumulation rates strongly depend on the successional stage, growth conditions or dynamic disturbance in forests.

Moreover, protected natural areas had the highest values of aboveground carbon. In this regard, Sharma et al. (2013) mentioned that the conservation of natural ecosystems for the purpose of maintaining ecological integrity contributes to the mitigation of climate change; however, these areas are also at high risk of carbon loss because of the effects of forest fires or pests that cause mass woodland death.

Another option for using land with high carbon stocks is to use it as sustainably managed forestland. Under this scheme, site productivity and changes in use are the main factors related to the capture and storage of aboveground carbon (Gonzalez-Benecke et al., 2015). Similarly, when comparing primary natural forests with high average carbon storage values with secondary forests, the secondary forests in tropical ecosystems have been shown to have only $40 \%$ as much carbon stored when compared with primary forests (Stas, 2014).

Although several studies have mentioned agroforestry as a land use with a high potential for carbon sequestration, in this review we found this forest type to have the lowest average of carbon stock; during this review, we found that Nair, Kumar, and Nair (2009) noted that the methodologies for estimating carbon in agroforestry systems are generally not rigorous, leading to inaccurate calculations. However, plantations, reforestation and agroforestry systems are options that must continue to be used in efforts to reduce rates of deforestation and may contribute significantly to climate change mitigation (Masera, Cerón and Ordoñez, 2001).

\section{CONCLUSIONS}

In Mexico, most studies that have estimated carbon in biomass have been based on generic concentrations of carbon $(50 \%)$ without differentiating between the carbon storage rates of various species. However, taxonomic groups should at least be considered when attempting to define the most appropriate carbon fraction used to esti- mate carbon stocks in forest ecosystems. In this review, we identified the need for more extensive studies of carbon at an ecosystem level, particularly in rainforests, where only a small number of studies have been conducted, which results in greater ambiguity in the reported carbon stocking rates. With this synthesis, we contribute to our understanding of the role of different forest ecosystems as carbon reservoirs and can recommend management options that contribute more aggressively to greater carbon capture and storage.

\section{ACIKNOWLEDGMENTS}

Funding was provided by UJED and Conacyt (222522). We also thank the editors and anonymous reviewers for their valuable comments.

\section{REFERENCES}

Aguirre-Calderón, O. and Jiménez-Pérez, J. (2011). Evaluación del contenido de carbono en bosques del sur de Nuevo León. Revista Mexicana de Ciencias Forestales, 2(6), 73-84.

Alvarado, M. F., Rodríguez, J. C. and Cerrato, M. (2007). Concentración de carbono y nitrógeno a seis frecuencias de poda en Gliricidia sepium y Erythrina sp. Tierra tropical, 3(2), 139-148.

Babst, F., Alexander, M. R., Szejner, P., Bouriaud, O., Klesse, S., Roden, J., Ciais, P., Poulter, B., Frank, D., Moore, D. J. P. and Trouet, V. (2014). A tree-ring perspective on the terrestrial carbon cycle. Oecologia, 176, 307-322. doi: 10.1007/s00442-014-3031-6

Baral, S. K., Malla, R. and Ranabhat, S. (2009). Above-ground carbon stock assessment in different forest types of Nepal. Banko Janakari, 19(2), 10-14. doi: 10.3126/banko. v19i2.2979

Bautista-Hernández, J. and Torres-Pérez, J. (2003). Valoración económica del almacenamiento de carbono del bosque tropical del ejido Noh Bec, Quintana Roo, México. Revista Chapingo. Series Forestales y del ambiente, 9(1), 69-75.

Campbell, M. M. and Sederoff, R. R. (1996). Variation in lignin content and composition (Mechanism of control and 
implications for the genetic improvement of plants. Plant Physiology, 110, 3-13.

Castaño-Santamaría, J. and Bravo, F. (2012).Variation in carbon concentration and basic density along stems of sessile oak (Quercus petraea(Matt.) Liebl.) and Pyrenean oak (Quercus pyrenaicaWilld.) in the Cantabrian Range (NW Spain).Annals of Forest Science, 69, 663-672. doi: 10.1007/s13595-012-0183-6.

Comisión Nacional Forestal (2012). Logros y perspectivas del desarrollo forestal en México 2007-2012. Zapopan, Jalisco: Comisión Nacional Forestal. Recuperado de http://www.conafor.gob.mx:8080/biblioteca/ver. aspx?articulo $=489$

Cunha-e-Sá, M., Rosa, R. and Costa-Duarte, R. (2013).Natural carbon capture and storage (NCCS): Forests, land use and carbon accounting. Resource and Energy Economics, 35, 148-170.

Dhillon, R. S. and von Wuehlisch, G. (2013). Mitigation of global warming through renewable biomass. Biomass Bioenergy, 48, 75-89. doi: 10.1016/j.biombioe.2012.11.005

Elias, M. and Potvin, C. (2003). Assessing inter- and intra-specific variation in trunk carbon concentration for 32 neotropical tree species. Canadian Journal of Forest Research, 33, 1039-1045. doi: 10.1139/x03-018

Gibbs, H. K., Brown, S., Niles, J. O. and Foley, J. A. (2007). Monitoring and estimating tropical forest carbon stocks: making REDD a reality. Environmental Research Letters, 2(4), 45023. doi: 10.1088/1748-9326/2/4/045023

Gonzalez-Benecke, C. A., Samuelson, L. J., Martin, T. A., Cropper, W. P., Johnsen, K.H., Stokes, T.A., Butnor, J. R. and Anderson, P. H. (2015). Modeling the effects of forest management on in situ and ex situ longleaf pine forest carbon stocks. Forest Ecology and Management, 355, 24-36. doi: 10.1016/j.foreco.2015.02.029

Hernández-Vásquez, E., Campos-Ángeles, G., Enríquez-Del Valle, J., Rodrígues-Ortiz, G. and Velasco-Velasco, V. (2012). Captura de carbono por Inga jinicuil Schltdl. en un sistema agroforestal de café bajo sombra. Revista Mexicana de Ciencias Forestales, 3(9), 11-21.

Hoch, G., Richter, A. and Korner, C. (2003). Non-structural carbon compounds in temperate forest trees. Plant, Cell \& Environment, 26,1067-1081.doi:10.1046/j.0016-8025.2003.01032.x
Intergovermental Panel on Climate Change [IPCC] (2006). Forest lands. Intergovernmental Panel on Climate Change Guidelines for National Greenhouse Gas Inventories (Vol. 4). Hayama, Japan: Institute for Global Environmental Strategies.

International Energy Agency [IEA] (2011). CO2 emissions from fuel combustion-Highlights 2011. Recuperado de http:// www.iea.org/media/statistics/co2highlights.pdf

International Energy Agency (2015). CO2 Emissions from fuel combustion highlights 2015. Recuperado de www.iea. org/publications/freepublications/publication/co2-emissions-from-fuel-combustion-highlights-2015.html

Jiménez-Pérez, J., Treviño-Garza, E. and Yerena-Yamallel, J. (2013). Concentración de carbono en especies del bosque de Pino-Encino en la Sierra Madre Oriental. Revista Mexicana de Ciencias Forestales, 4(17), 50-61.

Johnson, D. M., McCulloh, K. A., Woodruff, D. R. and Meinzer, F. C. (2012). Hydraulic safety margins and embolism reversal in stems and leaves: why are conifers and angiosperms so different? Plant Science, 195, 48-53. doi: 10.1016/j.plantsci.2012.06.010

Lamlom, S. H. and Savidge, R. A. (2003). A reassessment of carbon content in wood: variation within and between 41 North American species. Biomass and Bioenergy, 25(4), 381-388.

Martin, A. R. and Thomas, S. C. (2011). A reassessment of carbon content in tropical trees. PLoS One, 6, e23533. doi:10.1371/journal.pone.0023533.

Masera, O. R., Cerón, A. D. and Ordoñez, A. (2001). Forestry mitigation options for Mexico: finding synergies between national sustainable development priorities and global concerns. Mitigation and Adaptation Strategies for Global Change, 6, 291-312. doi: 10.1023/A:1013327019175

Murray-Tortarolo, G., Friedlingstein, P., Sitch, S., Jaramillo, V. J., Murguía-Flores, F., Anav, A. and Zeng, N. (2016). The carbon cycle in Mexico: past, present and future of $\mathrm{C}$ stocks and fluxes. Biogeosciences, 13(1), 223-238. doi: 10.5194/bg-13-223-2016

Nair, P. K. R., Kumar, B. M. and Nair, V. D. (2009). Agroforestry as a strategy for carbon sequestration. Journal of 
Plant Nutrition and Soil Science, 172(1), 10-23. doi: 10.1002/jpln.200800030.

Ordóñez D., J. A. B., Galicia N., A., Venegas M., N. J., Hernández T., T., Ordóñez D., M. J. and Dávalos-Sotelo, R. (2015). Densidad de las maderas mexicanas por tipo de vegetación con base en la clasificación de J. Rzedowski: compilación. Madera y Bosques, 21(núm. especial), 77-126. doi: 10.21829/myb.2015.210428

Ordóñez, J. A. B., de Jong, B. H. J., García-Oliva, F., Avila, F. L., Pérez, J. V., Guerrero, G., Martínez, R. y Masera, O. (2008). Carbon content in vegetation, litter, and soil under 10 different land-use and land-cover classes in the Central highlands of Michoacan, Mexico. Forest Ecology and Management, 255(7):2074-2084. doi: 10.1016/j. foreco.2007.12.024

Pineda-López, M. R., Sánchez-Velásquez, L. R., VázquezDomínguez, G. and Rojo Alboreca, A. (2013). The effects of land use change on carbon content in the aerial biomass of an Abies religiosa (Kunth Schltdl. et Cham.) forest in central Veracruz, Mexico. Forest Systems, 22(1), 82-93. doi: 10.5424/fs/2013221-02756

Poulter, B., Frank, D., Ciais, P., Myneni, R. B., Andela, N., Bi, J., Broquet, G., Canadell, J. G., Chevallier, F., Liu, Y. Y., Running, S., Sitch, S. and van der Werf, G. R. (2014). Contribution of semi-arid ecosystems to interannual variability of the global carbon cycle. Nature, 509, 600603. doi: 10.1038/nature13376

Ravindranath, N. H. and Ostwald, M. (2008). Carbon inventory methods: Handbook for greenhouse gas.Carbon Mitigation and Roundwood Production Projects. New York: Springer.

Razo-Zárate, R., Gordillo-Martínez, A. J., Rodríguez-Laguna, R., Maycotte-Morales, C. C. and Acevedo-Sandoval, O. A. (2013). Estimación de biomasa y carbono almacenado en árboles de oyamel afectados por el fuego en el Parque Nacional "El Chico", Hidalgo, México. Madera Bosques, 19(2), 73-86. doi: 10.21829/myb.2013.192341

Razo-Zárate, R., Gordillo-Martínez, A. J., Rodríguez-Laguna, R., Maycotte-Morales, C. C. and Acevedo-Sandoval, O. A. (2015). Coeficientes de carbono para arbustos y herbáceas del bosque de oyamel del Parque Nacional El Chico. Revista Mexicana de Ciencias Forestales, 6(31), 58-67.
Sarukhán, J., Koleff, P., Carabias, J., Soberón, J., Dirzo, R., Llorente-Bousquets, J. and de la Maza, J. (2009). Capital natural de México: conocimiento actual, evaluación y perspectivas de sustentabilidad. Síntesis. México, D.F.: Comisión Nacional para el Conocimiento y Uso de la Biodiversidad.

Sharma, T., Kurz, W. A., Stinson, G., Pellatt, M. G. and Li, Q. (2013). A 100-year conservation experiment: Impacts on forest carbon stocks and fluxes. Forest Ecology and Management, 310, 242-355. doi: 10.1016/j. foreco.2013.06.048

Silva-Arredondo, F. y Návar-Cháidez, J. (2009).Estimación de factores de expansión de carbono en comunidades forestales templadas del norte de Durango, México. Revista Chapingo Serie Ciencias Forestales y del Ambiente, 15(2), 155-160.

Stas, S. M. (2014). Above-ground biomass and carbon stocks in a secondary forest in comparison with adjacent primary forest on limestone in Seram, the Moluccas, Indonesia (Working Paper 145). Bogor, Indonesia: CIFOR.

Thomas, S.C. and Martin, A. R. (2012). Carbon content of tree tissues: A synthesis. Forests, 3, 332-352. doi: 10.3390/ f3020332

Torres-Rojo, J. M. and Guevara-Sanginés, A. (2002). El potencial de México para la producción de servicios ambientales: captura de carbono y desempeño hidráulico. Gaceta Ecológica, 63, 40-59.

Villanueva-López, G., Martínez-Zurimendi, P., CasanovaLugo, F., Ramírez-Avilés, L. and Montañez-Escalante, P. I. (2015). Carbon storage in livestock systems with and without live fences of Gliricidia sepium in the humid tropics of Mexico. Agroforestry Systems, 89(6), 1083-1096. doi: 10.1007/s10457-015-9836-4

Weedon, J. T., Cornwell, W. K., Cornelissen, J. H. C., Zanne, A. E., Wirth, C., and Coomes, D. A. (2009). Global metaanalysis of wood decomposition rates: a role for trait variation among tree species? Ecology Letters, 12(1), 45-56. doi: 10.1111/j.1461-0248.2008.01259.x

Whitehead, D. C. (2000). Nutrient elements in grassland: soilplant-animal relationships. New York: CAB International. 
Yerena, J. I., Jiménez, J., Aguirre, O. A. y Treviño, E. J. (2012). Contenido de carbono total de especies arbóreas y arbustivas en áreas con diferente uso, en el matorral espinoso tamaulipeco, en México. Bosque, 33(2):145-152. doi: 10.4067/S0717-92002012000200004

Zhang, Q., Wang, C., Wang, X. and Quan, X. (2009). Carbon concentration variability of 10 Chinese temperate tree species. Forest Ecology and Management, 258(5), 722727.
Received: 31 January 2017

Accepted: 6 April 2017

This paper must be cited as:

Pompa-García, M. and Sigala-Rodríguez, J. A. (2017). Variation of carbon uptake from forest species in Mexico: a review. Madera $y$ Bosques, 23(2), 225-235. doi: 10.21829.myb.2017.2321512 